\title{
Soil Mineralogy of Mangrove Forests from the State of São Paulo, Southeastern Brazil
}

\author{
V. S. Souza-Júnior \\ Univ. Federal Rural de Pernambuco/Unidade \\ Acadêmica de Serra Talhada \\ Fazenda Saco c.p. 063 \\ 56.900-000, Serra Talhada \\ Pernambuco \\ Brazil
}

\author{
P. Vidal-Torrado* \\ Depto. de Ciência do Solo \\ Escola Superior de Agricultura "Luiz de \\ Queiroz"/Univ. de São Paulo \\ Av. Pádua Dias 11 \\ 13.418-900, Piracicaba \\ São Paulo \\ Brazil
}

\section{T. Garcia-Gonzaléz \\ Instituto de Ciencias Agrarias/CSIC \\ Calle Serrano, 115, Dup \\ 28006 Madrid \\ Spain}

\section{L. Otero \\ F. Macías}

Depto. de Edafologia e Química Agrícola

Faculdade de Bioloxia

Univ. de Santiago de Compostela

15782 Santiago de Compostela

A Coruña

Spain

\begin{abstract}
The minerals of the clay fraction in estuarine plains are mainly detrital, being a mixture of marine and continental sediments, but can also be authigenic. Because of the importance of mangrove ecosystems in tropical estuarine areas and the relatively few existing studies of the mineralogical composition of soils in these environments, the aim of this study was to determine the mineralogical assemblage and identify potential contrasts along the coast of the State of São Paulo. Soils from 11 mangroves distributed along the coastal plain of the State of São Paulo were sampled at depths of 0 to 20 and 60 to $80 \mathrm{~cm}$, and samples of suspended sediments from the Ribeira do Iguape River were collected for analysis. Mineralogical analyses were performed on the clay and silt fractions by $\mathrm{x}$-ray diffraction (XRD) and transmission electron microscopy, and fresh soil samples were analyzed by scanning electron microscopy-energy dispersive spectrometry and suspended sediments by XRD. The silt fraction contained quartz, feldspars, gibbsite, kaolinite, illite, and vermiculite, and the clay fraction contained smectite, kaolinite, illite, gibbsite, quartz, and feldspars. Locally, vermiculite, biotite, anatase, halloysite, and goethite may occur because of recent transport of sediments to the system. Pyrite was identified in fresh samples. The allochthonous minerals found either were terrestrial and transported by rivers or had originated from the continental platform by past transgressive events. We suggest that the neoformation of smectite and kaolinite occurs in mangrove soils. Different geomorphological settings along the São Paulo coast appear to regulate mineral distribution in mangrove soils.
\end{abstract}

Abbreviations: IGUA, Caranguejo Island; ITA, Itapanhaú River; PM, Pai Matos Island; RE, Escuro River; RF, Fazenda River; XRD, x-ray diffraction.
$\mathrm{M}$ angroves are established in estuarine environments at the interface between marine and terrestrial environments and are affected by fluvial discharges and by the action of tidal currents. Consequently, the sediments that form mangrove soils are of both terrestrial and marine origin (Cooper, 2001; Anthony, 2004).

Despite the importance of these environments on the shorelines of tropical zones, relatively few studies have been performed. The existing studies have been mainly environ-

Soil Sci. Soc. Am. J. 72:848-857

doi:10.2136/sssaj2007.0197

Received 31 May 2007.

*Corresponding author (pablo@esalq.usp.br).

(c) Soil Science Society of America

677 S. Segoe Rd. Madison WI 53711 USA

All rights reserved. No part of this periodical may be reproduced or transmitted in any form or by any means, electronic or mechanical, including photocopying, recording, or any information storage and retrieval system, without permission in writing from the publisher. Permission for printing and for reprinting the material contained herein has been obtained by the publisher. mental in nature and involve retention processes and the geochemical behavior of trace metals (Clark et al., 1998; Andrade and Patchineelam, 2000; Marchand et al., 2006), nutrient and organic matter cycling (Alongi et al., 1998, 2005; Bosire et al., 2005), sedimentation dynamics (Furukawa et al., 1997; Smoak and Patchineelam, 1999), and paleoenvironmental reconstruction (Behling and Costa, 2001, 2004; Cohen et al., 2005).

The minerals present in estuarine areas are of mainly detrital origin, being mixtures of terrestrial and marine sediments. Terrestrial sediments become suspended in river water and are washed to estuarine areas, while marine sediments were deposited during past transgressive events or are continually deposited by tidal currents, although authigenesis may also occur in these environments (Chamley, 1989).

Relatively few of the studies involving mangrove soils have considered their mineralogical constitution. Such studies can contribute to our comprehension of the processes of distribution of heavy metals in the environment (Caliani et al., 1997; Dong et al., 2000; Liaghati et al., 2003). Furthermore, knowledge about mineralogical assemblages allows us to understand 
the physicochemical conditions occurring in the environment, as investigated by Velde and Church (1999), Dillenburg et al. (2000), and Ku and Walter (2003), who evaluated the stability and authigenesis of soil minerals in tidal plains. The mineralogical composition has also been used as a tracer of the origin of sediments in estuarine and marine environments (Petschick et al., 1996; Heroy et al., 2003).

The most important studies of the mineralogy of mangrove soils are those of Marius and Lucas (1991) in mangrove ecosystems on the shoreline of western Africa, where the predominance of quartz, kaolinite, and smectite in the soils was observed, as well as the presence of pyrite, jarosite, and halite. Studies have also been performed on the mangrove soils on the Australian eastern coast (New South Wales), in which quartz, kaolinite, illite, and feldspar were identified in the clay fraction (Smith, 1996).

In a study of Brazilian mangrove soils in the State of Espírito Santo, Marius et al. (1987) identified an assemblage constituted mainly of kaolinite and gibbsite, as well as illite and interlayered smectite-illite. These researchers attributed the presence of gibbsite in the mangrove soils to the supply of coastal Tertiary sediments from the Barreiras Formation, which correspond to areas adjacent to the estuary. The presence of gibbsite as well as illite, illite-smectite, and kaolinite was also observed in sediments from Guanabara Bay in Rio de Janeiro (Faria and Sanchez, 2001). In mangrove ecosystems in the Amazon region, Behling and Costa (2004) and Costa et al. (2004) identified mainly smectite, kaolinite, and pyrite, as well as anatase, feldspar, and halite. Recently, in the State of São Paulo, Prada-Gamero et al. (2004) identified minerals of allochthonous origin (kaolinite and mica) and others of autochthonous origin (smectite and Fe-mica) in the clay fraction of a mangrove soil in the Baixada Santista region.

Due to the lack of detailed studies of the mineralogical composition of mangrove soils and in view of the relevance of the topic to scientists investigating coastal environments, the aim of the present study was to determine the representative mineralogical assemblages in the clay and silt size fraction, and to identify potential contrasts among them in the different sectors on the coast of the State of São Paulo (Brazil). For this, the mineral constituents were identified in 11 mangrove soils, which were selected according to their geomorphological position on the coast of the State of São Paulo.

\section{MATERIALS AND METHODS}

The typical climate along most of the shoreline of São Paulo State is Afa, according to the Köeppen classification (Rossi, 1999). The climate is tropical with a mean annual temperature of $>18^{\circ} \mathrm{C}$ and annual precipitation that varies between 1600 and $2000 \mathrm{~mm}$, and does not present a seasonal winter draft (Rossi, 1999).

Geomorphologically, the coast of São Paulo State is divided into two distinct regions. In the northern region, virtually the entire extension of the crystalline basement reaches the sea and mangrove forests are relatively scarce, small, and concentrated at the river mouth. The southern region comprises large plains, essentially formed by marine or fluvial-lacustrine deposits (Suguio and Martin, 1978). Mangrove forests are common there and are distributed along the several channels and rivers of the Cananéia-Iguape lagoon estuarine system. The Baixada Santista region is located in the central zone, linking the two distinct regions. It is slightly cut by the crystalline basement and also comprises a large coastal plain. There are also several mangrove forests associated with the Santos estuary (Lamparelli, 1998) in this region. The crystalline basement mainly consists of granites, gneisses, schists (mica schists and quartz schists), and migmatites, with some alkaline rocks present (Comissao de Solos, 1960).

The mangrove forests under study are located in the three areas of the coast of São Paulo State (Fig. 1). In the southern area, the following mangrove forests were sampled: Sítio Grande River (sampled at two points: SG1 and SG2), Ipaneminha River (IPA), and the transition between the Restinga and Ipaneminha rivers (TRA), Pai Matos Island (PM), Baguaçu Island (BAG), and Caranguejo Island (IGUA). Itapanhaú River (ITA) and Guaratuba River (GUA) mangrove forests in the Baixada Santista estuary were also sampled. In the northern area, Escuro River (RE) and Fazenda River (RF) mangrove forests were sampled.

The samples were collected with a sampler for flooded soils at depths of 0 to $20 \mathrm{~cm}$ (surface layer) and 60 to $80 \mathrm{~cm}$ (subsurface layer). In the field, the redox potential (Eh) and $\mathrm{pH}$ were determined in the sampled layers with portable devices. The final Eh measurements, obtained with a platinum electrode, were corrected by the addition of the potential of the saturated

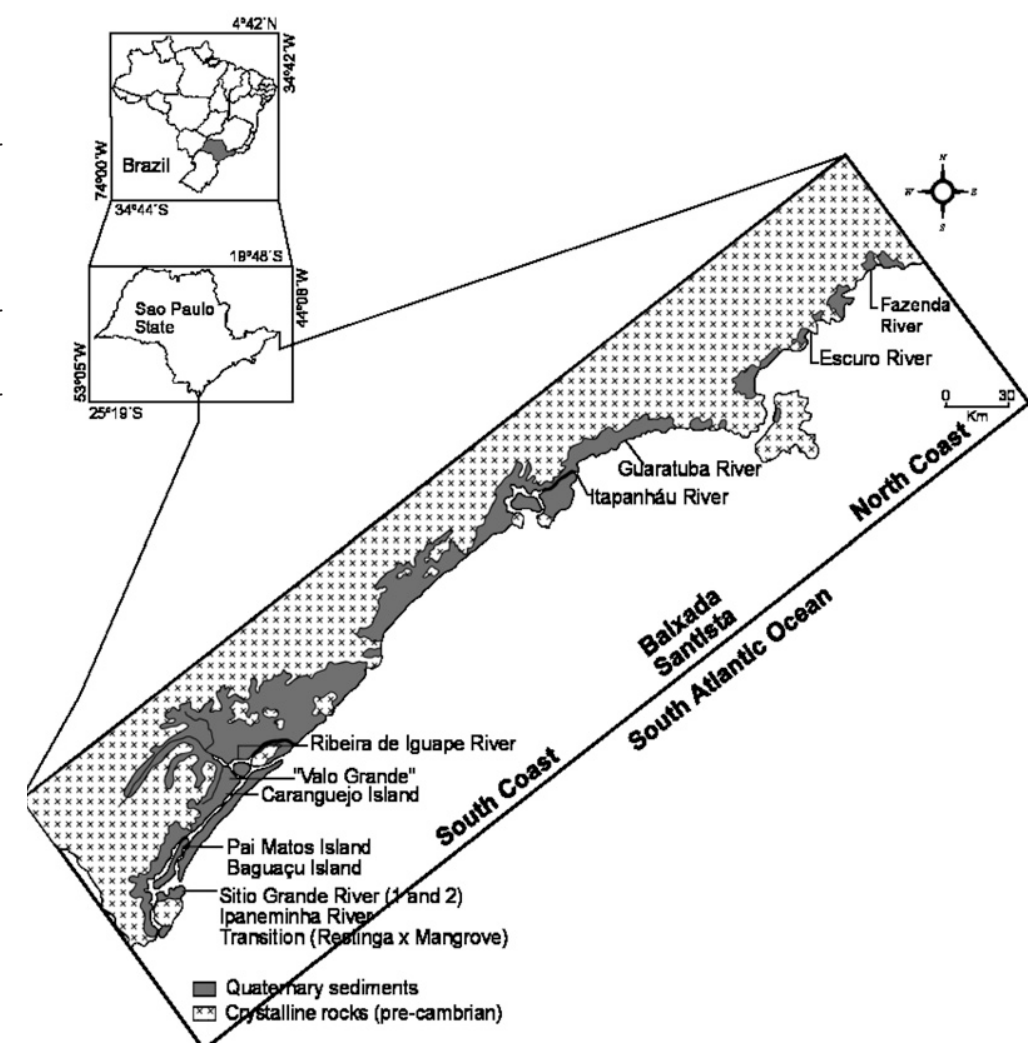

Fig. 1. Geology and division of the coastal plain in the state of São Paulo (modified from Suguio and Tessler, 1992). The location of the sampling points is shown. 
calomelane electrode used as a reference electrode $(244 \mathrm{mV})$, and the $\mathrm{pH}$ measurements were obtained with a glass electrode calibrated with standard solutions at $\mathrm{pH} 4.0$ and 7.0.

To evaluate the mineralogy of the sediment that reaches the estuary, suspended sediments were collected from the main river in the southern area, the Ribeira do Iguape River, in Valo Grande next to an old dam. A pumping system was used to collect $200 \mathrm{~L}$ of water, which was stored in plastic containers and transported to the laboratory to obtain the sediment.

The soil samples were treated to remove organic matter and soluble salts. The sand and silt-plus-clay fractions were then separated by moist sieving and then the silt and clay were separated by decantation (Jackson, 1969).

$\mathrm{X}$-ray diffraction (XRD) analysis was done on glass slides for oriented aggregates of the clay fraction saturated with $\mathrm{Mg}^{2+}$ and $\mathrm{K}^{+}$, and for random powder mounts of unsaturated clays and silt fractions. The $\mathrm{K}^{+}$-saturated samples were analyzed at $25^{\circ} \mathrm{C}(\mathrm{K} 25)$ and after heating to $300^{\circ} \mathrm{C}(\mathrm{K} 300)$ and $550^{\circ} \mathrm{C}$ (K550) for $3 \mathrm{~h}$, whereas the samples saturated in $\mathrm{Mg}^{2+}$ were pro-
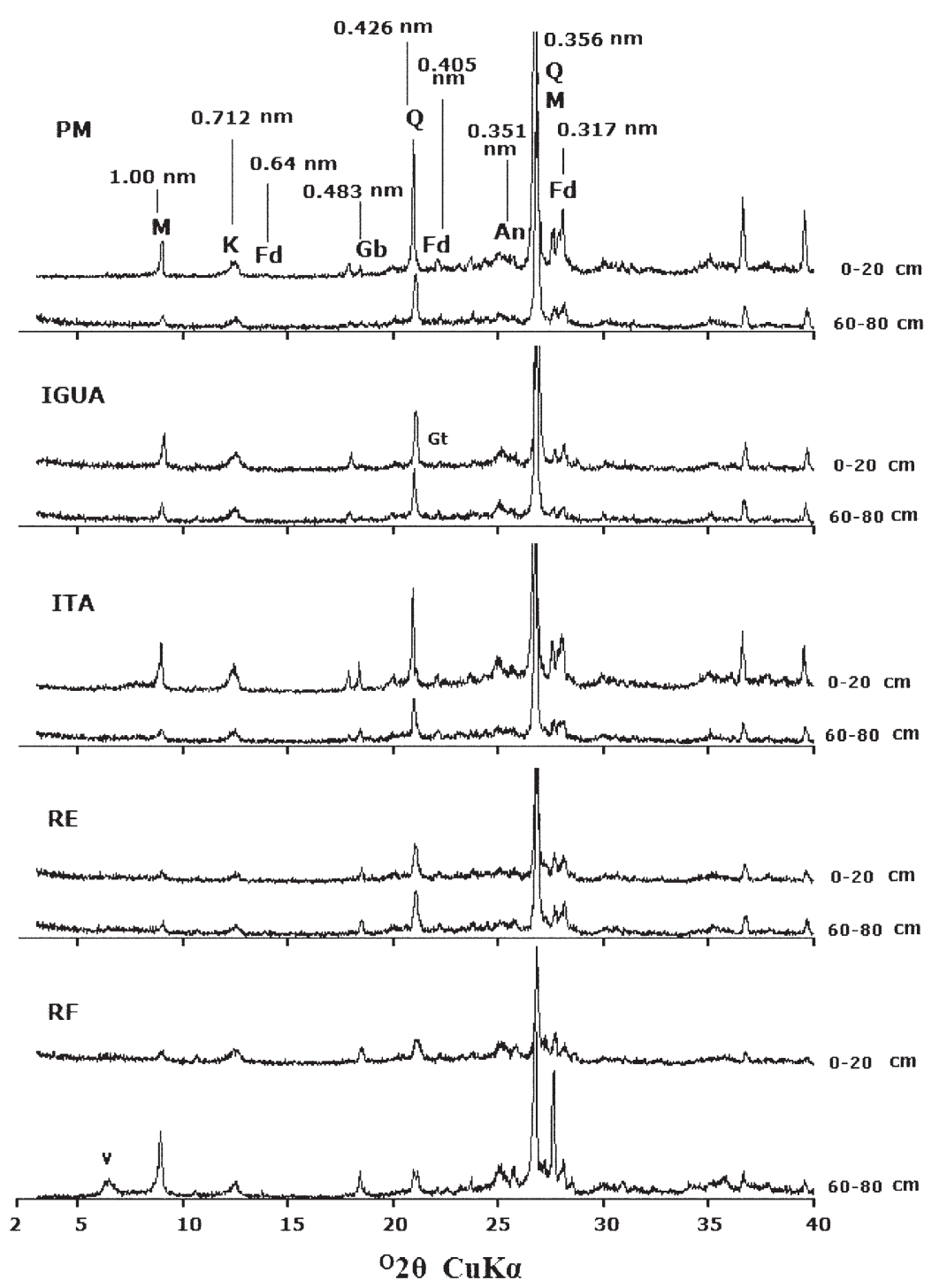

Fig. 2. X-ray diffraction patterns of the silt fraction of mangrove soils from Pai Matos Island (PM), Caranguejo Island (IGUA), Itapanhaú River (ITA), Escuro River (RE), and Fazenda River (RF) at depths of 0 to 20 and 60 to $80 \mathrm{~cm} ; \mathrm{M}=$ mica, $\mathrm{K}=$ kaolinite, $\mathrm{Fd}=$ feldspar, $\mathrm{Gb}=$ gibbsite, $\mathrm{An}=$ anatase, $\mathrm{Q}=$ quartz, $\mathrm{Gt}=$ goethite, $\mathrm{V}=$ vermiculite. cessed like oriented aggregates and were also solvated in ethylene glycol (Mg-E). In addition, the concentration of Fe oxides was determined by dissolution in $\mathrm{NaOH}\left(5 \mathrm{~mol} \mathrm{~L}^{-1}\right)$, according to Kämpf and Schwertmann (1982), in the samples of the clay fraction of IGUA and PM, which had been processed as random powder. The analysis of the sediment sample was performed on bulk samples as oriented aggregates without any pretreatments.

The XRD patterns were obtained by a Philips PW 1130 diffractometer with a graphite monochromator, using $\mathrm{Cu}-\mathrm{K} \alpha$ radiation and applying $45 \mathrm{kV}$ and a $40 \mathrm{~mA}$ current, with a scanning rate of $0.02^{\circ} 2 \theta s^{-1}$.

Transmission electron microscopy was used to analyze the clay fraction with the aim of identifying the morphology of the minerals present. For this, a transmission electron microscope Model STEM LEO 910 (Carl Zeiss, Oberkochen, Germany) was used. The samples were dispersed in dilute aqueous $\mathrm{NH}_{3}$ after drying in a copper net and, finally, they were recovered with a carbon pellicle.

The images of pyrite were obtained from the dense fraction of the fresh soil sample, which was separated with bromoform (density of $2.89 \mathrm{~kg} \mathrm{~L}^{-1}$ ). The sample was observed in a scanning electronic microscope, Model LEO 435 VP analyzer (Leica, Cambridge, UK), fitted with an energy dispersive spectrometry analysis system, Model Oxford ISIS 300 (Oxford Univ., Oxford, $\mathrm{UK})$, at $20 \mathrm{kV}$ and waiting time of $100 \mathrm{~s}$.

The semiquantitative estimations of quartz, gibbsite, goethite, and total phyllosilicates was performed by examination of the XRD patterns of random powder mounts by integration of the area of maximum diffraction at $0.426,0.483,0.418$, and $0.444 \mathrm{~nm}$, respectively, for those minerals, and by using intensity factors, according to Schultz (1964) and Biscaye (1965). The relative abundance of kaolinite, smectite, vermiculite, and mica was estimated similarly, by examination of the XRD patterns of samples saturated with $\mathrm{Mg}^{2+}$, in peak areas at 0.72 $\mathrm{nm}$ for kaolinite, $1.00 \mathrm{~nm}$ for mica, $1.41 \mathrm{~nm}$ for vermiculite, and $1.64 \mathrm{~nm}$ for smectite from samples in $\mathrm{Mg}$-E. Due to the applied method, the presented values do not have an absolute meaning, but they present internal values relative to the samples.

\section{RESULTS Silt Fraction}

The XRD patterns of the silt fraction in the PM, IGUA, ITA, RE, and RF samples are shown in Fig. 2. The minerals identified were quartz, feldspar, gibbsite, kaolinite, illite, and vermiculite; the latter was found only in RF.

Quartz was identified by diffraction peaks at basal spacings of $0.426,0.334$, and $0.182 \mathrm{~nm}$, and feldspar by peaks at $0.64,0.405,0.378,0.322$, and $0.317 \mathrm{~nm}$. Gibbsite was identified in all samples analyzed, by peaks at 0.483 and $0.437 \mathrm{~nm}$. The gibbsite gradient was apparent along the shoreline, with the highest intensities of peaks corresponding to samples from the north and the lowest to samples from the south. 
Mica was identified by peaks at $1.00,0.5$, and $0.334 \mathrm{~nm}$. In the samples from the northern region (RE and RF), however, the $0.5-n m$ peak was observed either at very low intensity or was absent. Kaolinite was identified by the presence of peaks at 0.712 and $0.356 \mathrm{~nm}$ in the silt fraction of these soils (Fig. 2).

The presence of vermiculite was observed in the RF mangrove soil, mainly at a depth of 60 to $80 \mathrm{~cm}$. The XRD patterns obtained with random powder mounted silt, silt on oriented aggregates, solvated in ethylene glycol, and heated to $550^{\circ} \mathrm{C}$ are shown in Fig. 3a. According to the patterns shown, there is a peak at $1.4 \mathrm{~nm}$, which was not displaced after treatment with ethylene glycol, but collapsed after heating to $550^{\circ} \mathrm{C}$.

\section{Clay Fraction}

The XRD patterns were determined for all samples collected, although only data corresponding to the following sites is shown: PM and IGUA, on the southern shoreline; ITA, which represents the mangrove forests of the Baixada Santista; and RE and RF sampled on the north shoreline. This set of samples was considered representative of the three studied areas.

According to the XRD patterns obtained (Fig. 4-7), the mineralogical assemblage of the clay fraction of soils consisted of smectite, vermiculite, illite, kaolinite, gibbsite, goethite, quartz, and feldspars. As in the silt fraction, the accessory minerals found and identified in all the samples were quartz, feldspars, and mainly gibbsite.

Goethite was identified in IGUA by the diffraction peak at a basal spacing $0.418 \mathrm{~nm}$ (Fig. 3b and 5). Treatment with concentrated Fe and heating to $550^{\circ} \mathrm{C}$ revealed the presence of anatase in the clay fraction, which was identified by the peak at $0.351 \mathrm{~nm}$ in the PM and IGUA samples (Fig. 3b) and also in the silt fraction (Fig. 2).

Mica and kaolinite were found at all sampling points. Mica was identified by the peaks at $1.00,0.50$, and $0.334 \mathrm{~nm}$, and it must be pointed out that in the northern mangrove forest soils (Fig. 7), the 0.50 -nm peak occurred at a very low intensity when compared with the $1.00-\mathrm{nm}$ peak. Kaolinite was demonstrated by the presence of peaks at 0.712 and 0.356 $\mathrm{nm}$, which disappeared after heating to $550^{\circ} \mathrm{C}$. Kaolinite presented generally intense peaks at similar levels in almost all samples, of low intensity only in the subsuperficial samples of ITA and RF.

Except in the RF mangrove soils, smectite was identified in all the samples by the presence of a peak at $1.41 \mathrm{~nm}$, which changed to 1.68 $\mathrm{nm}$ in $\mathrm{Mg}$-E. The highest intensity of the peak corresponded to the PM mangrove soil, and the lowest intensity to the IGUA soil, mainly in the subsuperficial layer. The ITA and RE samples showed similar patterns to each other, with the level of peak intensity intermediate between the levels of PM and IGUA. The 1.41-nm peak did not change position after treatment in ethylene glycol and collapsed to $1.00 \mathrm{~nm}$ in $\mathrm{K} 550$, proving the presence of vermiculite in the RF soils (Fig. 7).

The semiquantitative data for phyllosilicates and some accessory minerals are shown in Table 1 . The results show that the most abundant phyllosilicate in PM and IGUA was kaolinite (38-55\%), except in the subsurface of PM, in which smectite prevailed (36\%). Traces of gibbsite and quartz were found in these mangrove soils, with the latter mainly occurring $(11 \%)$ in the subsurface of PM. Goethite was present in small amounts in the 0 - to 20 - and 60- to 80-cm layers of the IGUA mangrove soil (1 and 3\%, respectively). In the Baixada Santista, smectite was the most abundant phyllosilicate in the ITA mangrove forest soil (36 and 66\% in the surface and subsurface, respectively), with gibbsite (1\%) and traces of quartz also occurring. The northern mangrove soils presented a significantly higher amount of gibbsite than the other mangrove soils, with values varying between 2 and $24 \%$ and the highest concentrations in RF (14 and 24\%), highlighting an increasing gradient of concentration moving northward along the shoreline for this mineral. Trace amounts of quartz were found in these mangrove soils and there was a predominance of smectite in RE (39 and 38\%), whereas RF presented a greater abundance of kaolinite in the surface (54\%) and mica in the subsurface $(60 \%)$. Transmission electron microscopy enabled observation of the morphology of some minerals identified by XRD, such as kaolinite, which presented a plain hexagonal shape (Fig.
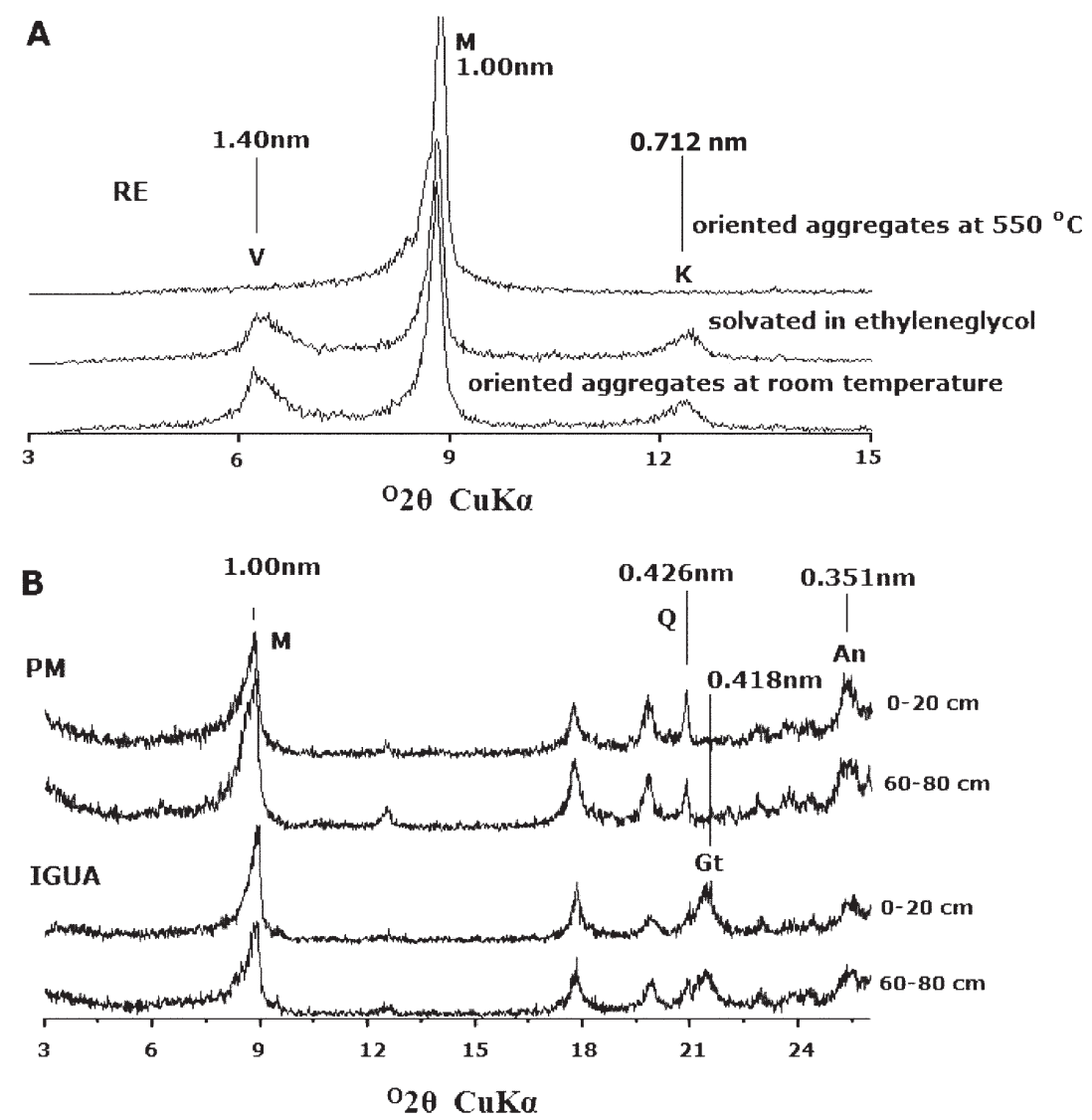

Fig. 3. X-ray diffraction patterns of (a) the Escuro River (RE) silt fraction $(60-80 \mathrm{~cm})$ on oriented aggregates at room temperature, heated to $550^{\circ} \mathrm{C}$, and solvated in ethylene glycol, and (b) the clay fraction, after concentration of Fe, from Pai Matos Island (PM) and Caranguejo Island (IGUA) mangrove soils at depths of 0 to 20 and 60 to $80 \mathrm{~cm} ; \mathrm{V}=$ vermiculite, $M=$ mica, $K=$ kaolinite, $Q=$ quartz, $G t=$ goethite, $A n=$ anatase. 
Pai Matos Island mangrove
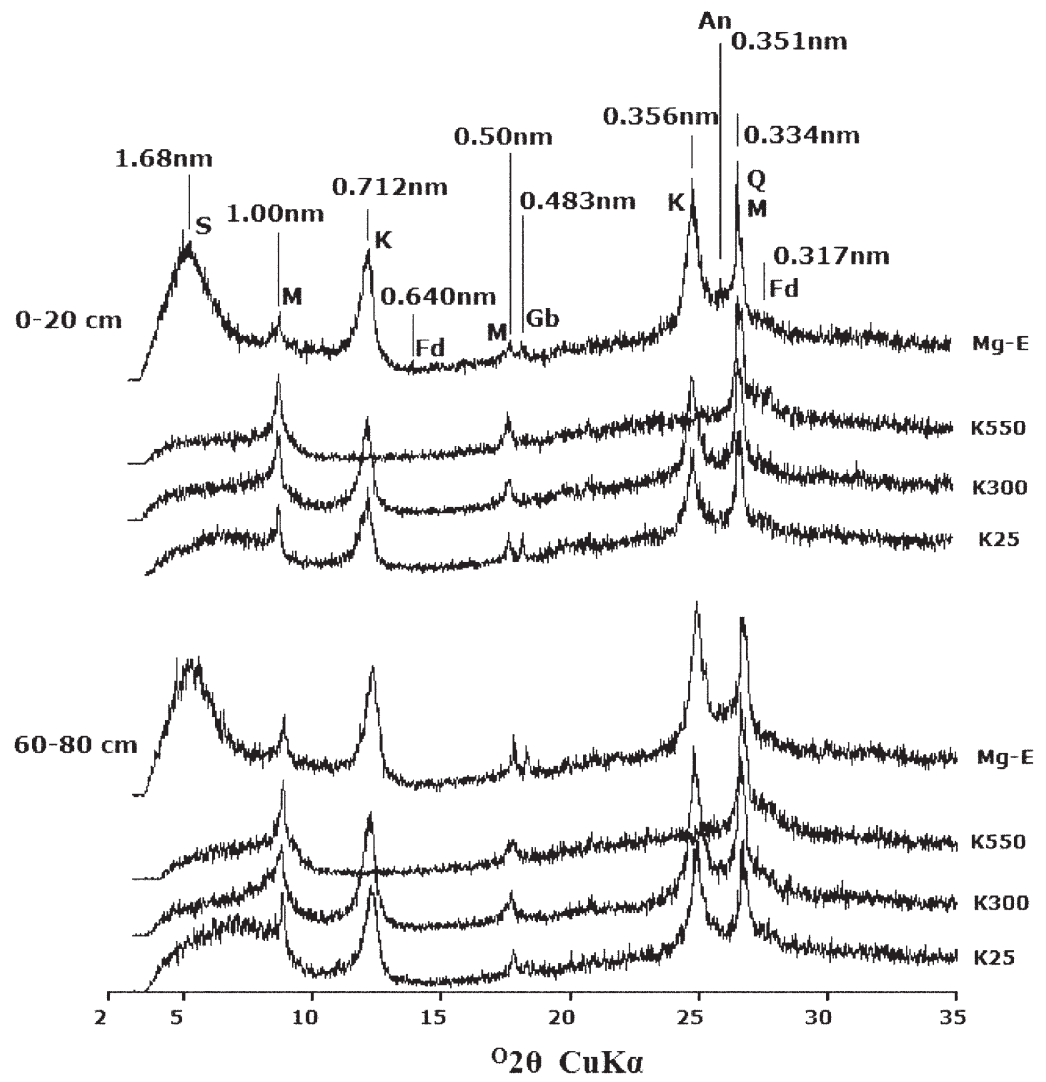

Fig. 4. X-ray diffraction patterns of the clay fraction of the Pai Matos Island mangrove soil at depths of 0 to 20 and 60 to $80 \mathrm{~cm} ; S=$ smectite, $M=$ mica, $K=$ kaolinite, Fd = feldspar, $G b=$ gibbsite, $Q=$ quartz, An = anatase.

\section{Caranguejo Island mangrove}

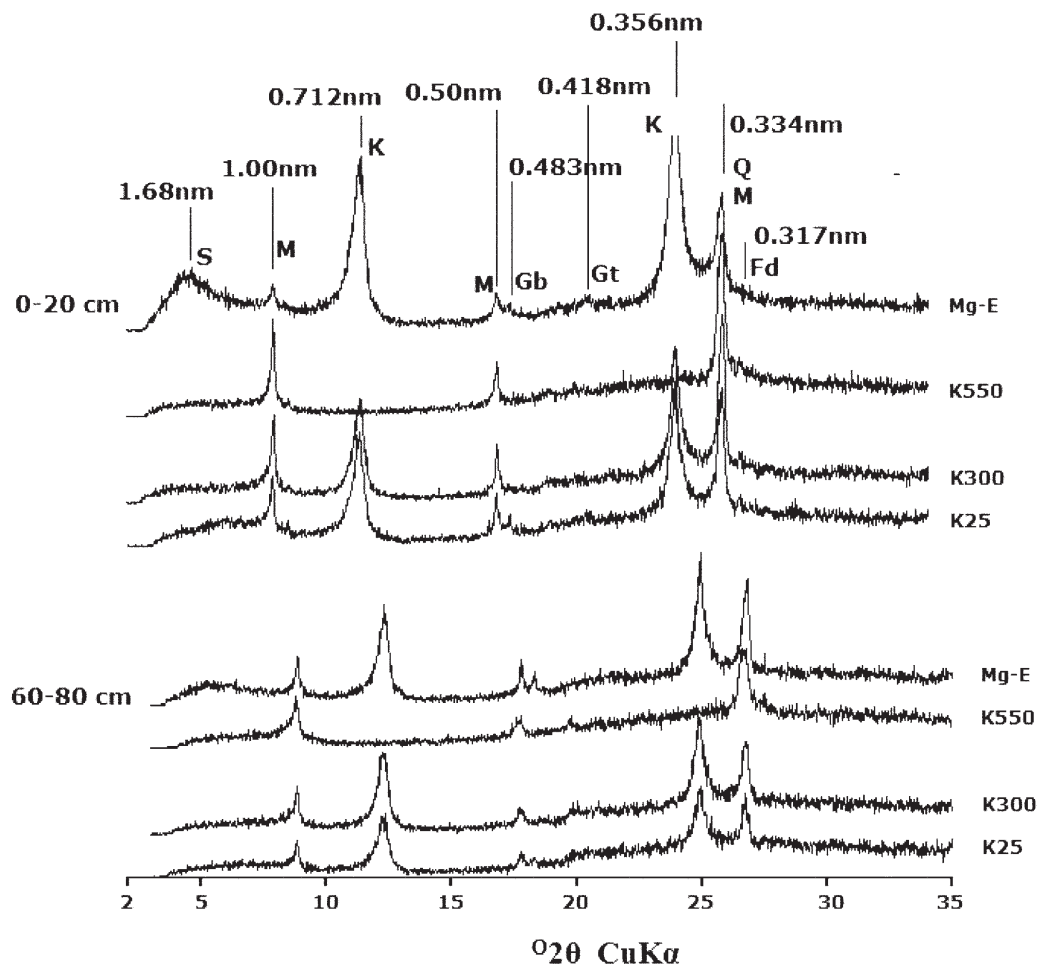

Fig. 5. X-ray diffraction patterns of the clay fraction of the Caranguejo Island mangrove soil at depths of 0 to 20 and 60 to $80 \mathrm{~cm} ; S=$ smectite, $M=$ mica, $K=$ kaolinite, $\mathrm{Fd}=$ feldspar, $\mathrm{Gb}=$ gibbsite, $\mathrm{Gt}=$ goethite, $\mathrm{Q}=$ quartz, $\mathrm{An}=$ anatase. 8a). The morphology observed in the images in Fig. $8 \mathrm{c}$ and $8 \mathrm{~d}$ can be attributed to the shapes of vermiculite and smectite, respectively. The structures resembling long tubes (Fig. 8a and $8 \mathrm{~b}$ ) suggest the presence of the tubular form of halloysite in the clay fraction in soils of the RE mangrove forest.

\section{Fluvial Suspended Sediment and Fresh Samples}

The XRD pattern of sediment from Ribeira do Iguape River is shown in Fig. 9. Most of the minerals identified were the same as those found in the silt and clay fractions of the mangrove soils studied (mica, kaolinite, gibbsite, quartz, and feldspars), although there was also a mineral with a peak at $1.4 \mathrm{~nm}$, probably vermiculite. Goethite was also observed in the suspended sediments.

Scanning electronic microscopy and microanalysis enabled identification of pyrite framboids in the sample from the ITA mangrove forest (Fig. 10).

\section{DISCUSSION}

The minerals that occur in estuarine areas are mainly detrital in origin, being a mixture of terrestrial and marine sediments. The former are transported in suspension by rivers and the latter are deposited as a result of past transgression events or are currently deposited by tidal currents, although authigenesis is also thought to occur in this environment (Chamley, 1989). The mineralogical assemblages characterized in the present study have occurred as a result of these processes.

The different peaks corresponding to feldspar may indicate the presence of either potassic feldspars or plagioclases. The presence of these minerals in soils generally is related to the sand and silt fractions, although they are also reported to occur in the coarse clay fraction and rarely in the fine clay fraction (Brown, 1980). Quartz follows a pattern similar to the feldspars regarding occurrence, according to the granulometry presented in a review by Drees et al. (1989). These minerals originate from the weathering of rocks of the crystalline complex of the Serra do Mar, the primary source of minerals to the sediments of the São Paulo coastal plain, but may also originate from sandy coastal sediments transported during the last Holocenic transgressive events.

Particle abrasion, which is typical in the environment studied, explains the fractionation and maintenance of primary minerals in the clay fraction of mangrove soils, which in turn is related to the stability ensured by the geochemical environment rich in basic cations provided by the sea water and the high concentration of biogenic $\mathrm{Si}$, as described by Michalopoulos and Aller (2004). The presence of anatase in mangrove soils is related to the terrestrial origin of the sediments and to the 
strong resistance of this mineral to weathering (Milnes and Fitzpatrick, 1989).

Crystalline Fe oxyhydroxides, such as goethite, are unstable in anoxic $\mathrm{SO}_{4}$-reducing conditions and can be readily reduced by microbial activity and transformed into pyrite in a very short period (days) (Canfield et al., 1993). The main end product of $\mathrm{SO}_{4}$ reduction in these types of environments should be pyrite (Howarth and Merkel, 1984). In the present study, the $\mathrm{pH}-\mathrm{Eh}$ conditions are close to the stability field of pyrite (see, e.g., Fanning et al., 2002), which is consistent with the presence of this mineral in these soils (Table 2, Fig. 10). In a study involving sequential chemical extraction, Ferreira et al. (2007b,c) also found that pyrite is the most abundant form in mangrove soils from the southern shoreline and Baixada Santista.

This redox process explains the absence of goethite in the XRD patterns for most of the soils. Previous studies, in which the selective extraction for Fe oxyhydroxidase proposed by Fortin et al. (1993) was applied to some of these mangrove soils, showed $29.8 \pm 19 \mathrm{mmol} \mathrm{kg}^{-1}$ of Fe-goethite $(n=46)$ (Ferreira, 2006, 2007a,b,c); however, the extracted quantities were $<0.3 \%$ of the bulk soil, which is why it was not detected by XRD. Concentrations below $100 \mathrm{mmol} \mathrm{kg}^{-1}$ of Fe oxyhydroxide are considered the limit for $\mathrm{SO}_{4}$ reduction to begin (Van Cappellen and Wang, 1996) and are consistent with the persistence of these minerals in anoxic environments (Lovley, 1991).

Goethite was detected by XRD in the IGUA soil because of the particular conditions that occur in this area. The IGUA mangrove forest is located close to the Valo Grande, i.e., in the mouth of a branch of the river Ribeira do Iguape. The suspended sediments, which contain goethite, are deposited directly on the IGUA soil (Fig. 3b). Further study is

$60-80 \mathrm{~cm}$
Itapanhaú River mangrove
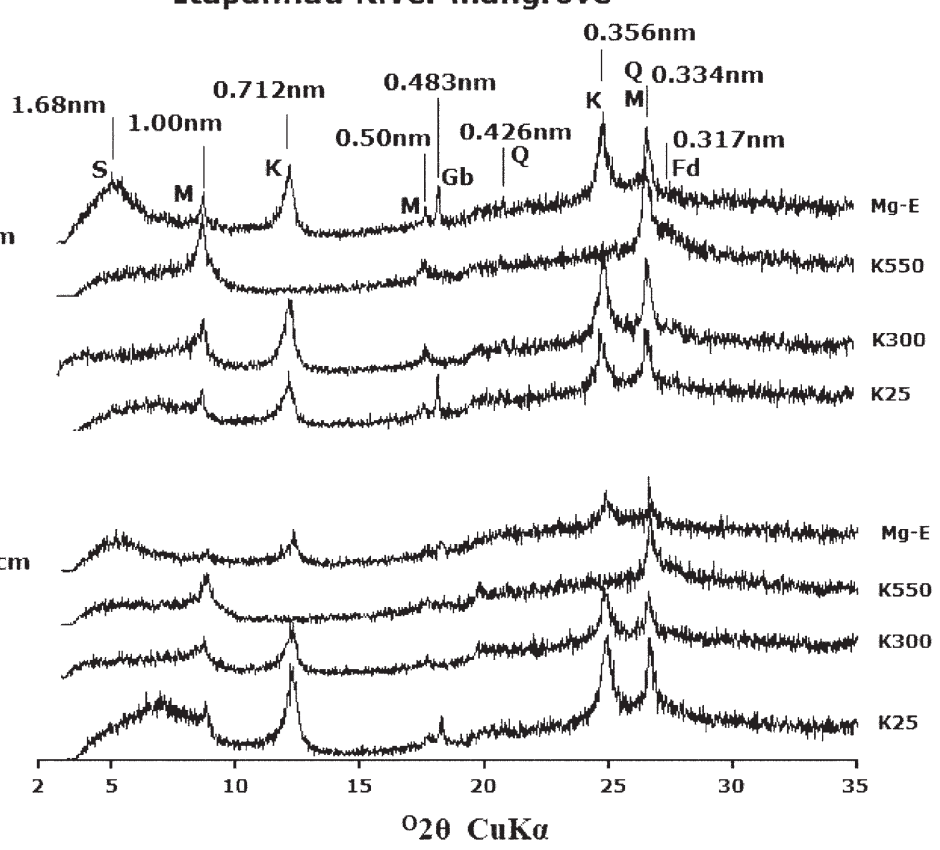

Fig. 6. X-ray diffraction patterns in the clay fraction of the Itapanhaú River mangrove soil at depths of 0 to 20 and 60 to $80 \mathrm{~cm} ; S=$ smectite, $M=$ mica, $K=$ kaolinite, $\mathrm{Fd}=$ feldspar, $\mathrm{Gb}=$ gibbsite, $\mathrm{Q}=$ quartz, $\mathrm{An}=$ anatase.

required, however, regarding the presence of goethite at depth. Bioturbation by crabs may explain the presence of this mineral at depth. The effects of this kind of bioturbation on the geochemical behavior of Fe in mangrove soils in Brazil have been discussed by Ferreira et al. (2007b).

Pyrite is formed by the reduction of $\mathrm{Fe}^{3+}$ supplied by terrestrial sediments and $\mathrm{SO}_{4}{ }^{2+}$ supplied by sea water, and the reaction is mainly promoted by $\mathrm{SO}_{4}$-reducing bacteria (Desulfovibrio spp.) (Doner and Lynn, 1989). This mineral occurs as individual cubes in the clay fraction and as framboids in the silt fraction (Fanning et al., 2002).

\section{Escuro River mangrove}

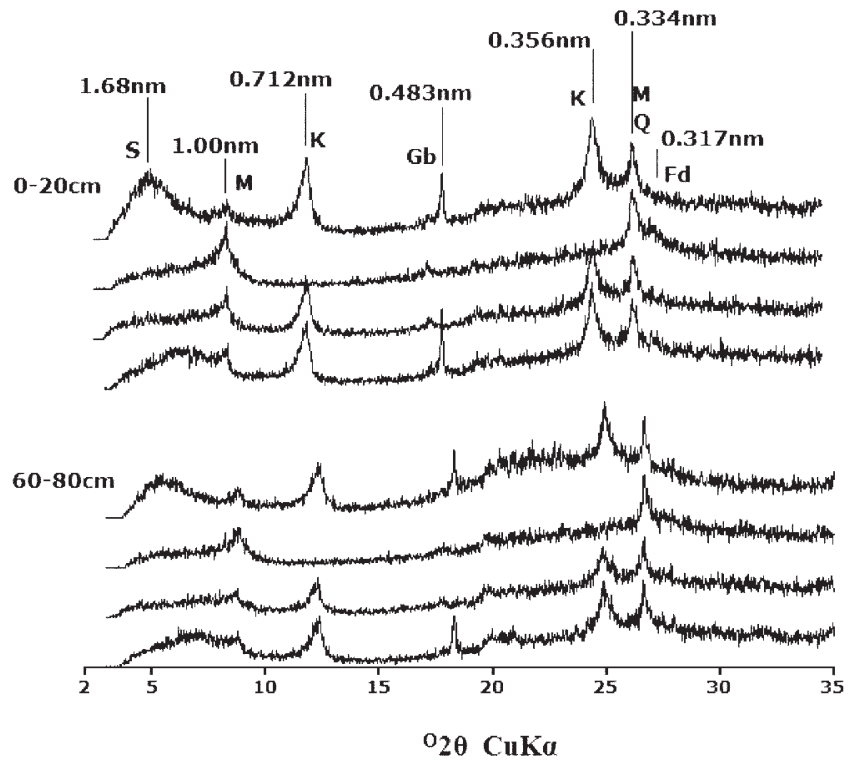

Fazenda River mangrove

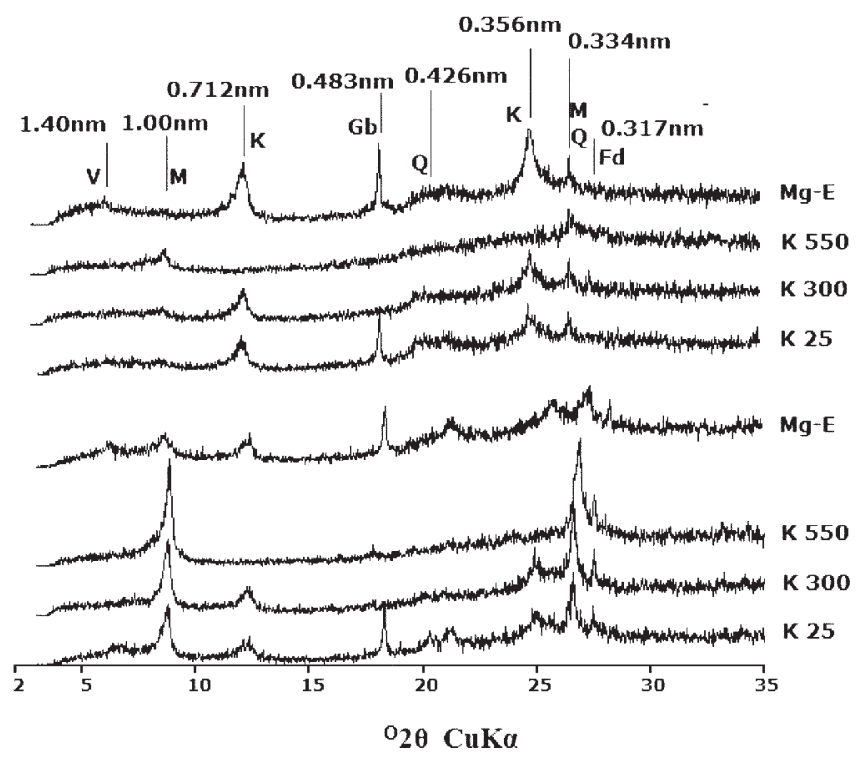

Fig. 7. X-ray diffraction patterns of the clay fraction of the Escuro River and Fazenda River mangrove soils at depths of 0 to 20 and 60 to $80 \mathrm{~cm}$; = smectite, $\mathrm{V}=$ vermiculite, $\mathrm{M}=$ mica, $\mathrm{K}=$ kaolinite, $\mathrm{Fd}=$ feldspar, $\mathrm{Gb}=$ gibbsite, $\mathrm{Q}=$ quartz, $\mathrm{An}=$ anatase. 
Table 1. Semiquantitative estimation of the mineralogical composition of the clay fraction (relative percentage in samples) of mangrove soil samples from the Pai Matos Island (PM), Caranguejo Island (IGUA), Itapanhaú River (ITA), Escuro River (RE), and Fazenda River (RF) sites.

\begin{tabular}{|c|c|c|c|c|c|c|}
\hline Site and depth & Gibbsite & Goethite & Quartz & Smectite & Illite & Kaolinite \\
\hline \multirow[t]{2}{*}{$\mathrm{cm}$} & & +2 & +2 & 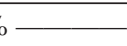 & & 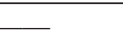 \\
\hline & \multicolumn{5}{|c|}{$\underline{\text { South shoreline }}$} & \multirow[b]{2}{*}{38} \\
\hline PM 0-20 & TRt & ND $\ddagger$ & TR & 30 & 32 & \\
\hline PM 60-80 & $\mathrm{TR}$ & ND & 11 & 36 & 27 & 26 \\
\hline IGUA 0-20 & $\mathrm{TR}$ & 1 & TR & 19 & 25 & 55 \\
\hline IGUA 60-80 & 1 & 3 & TR & 15 & 26 & 55 \\
\hline \multicolumn{7}{|c|}{ Baixada Santista } \\
\hline ITA 0-20 & 1 & ND & TR & 36 & 32 & 32 \\
\hline ITA 60-80 & 1 & ND & TR & 66 & 10 & 23 \\
\hline \multicolumn{7}{|c|}{$\underline{\text { North shoreline }}$} \\
\hline RE 0-20 & 2 & ND & TR & 39 & 28 & 31 \\
\hline RE 60-80 & 5 & ND & ND & 38 & 27 & 30 \\
\hline RF 0-20 & 14 & ND & ND & $13 \S$ & 19 & 54 \\
\hline RF 60-80 & 24 & ND & $\mathrm{TR}$ & $2 \S$ & 60 & 14 \\
\hline
\end{tabular}

$+\mathrm{TR}=$ trace.

$\neq \mathrm{ND}=$ not detected

$\S$ Refers to vermiculite.

The soils in areas adjacent to the coastal plain in São Paulo State present a mineralogical assemblage that is mainly com-
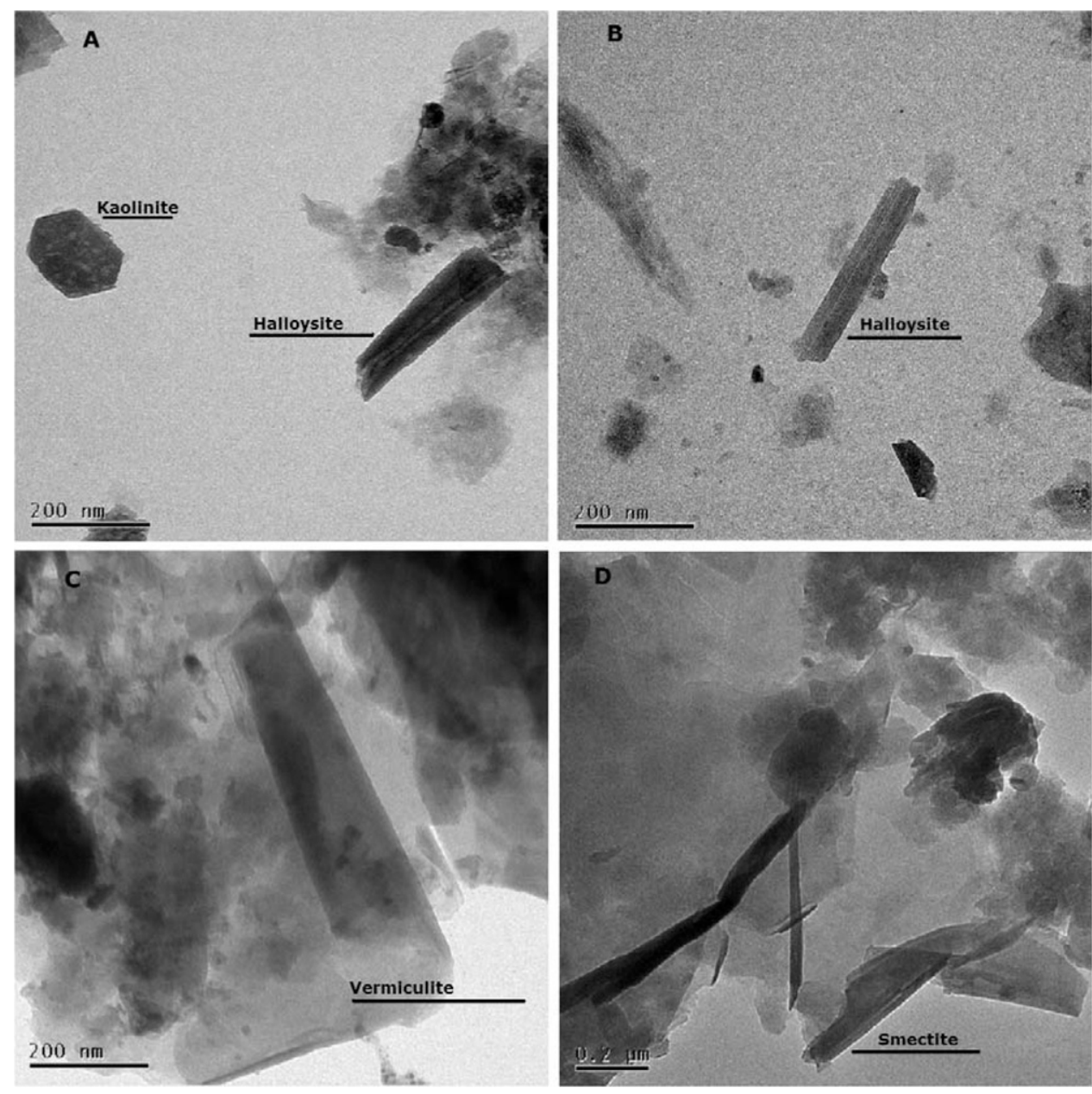

Fig. 8. Transmission electron micrographs showing: (A) plain hexagonally shaped kaolinite and tubular halloysite; (B) tubular halloysite; (C) vermiculite; and (D) smectite in Escuro River mangrove soil. prised of kaolinite and gibbsite (Rossi, 1999; Furian et al., 2002; Ishida, 2005). This explains the presence of gibbsite in the mangrove soils under study. The decrease in the gibbsite levels moving southward along the shoreline (Fig. 4-7, Table 1) may be related to the longer distance between the mangrove forests and the Serra do Mar. Thus, northern mangrove soils, which are located closer to the source, presented higher levels of gibbsite. Southern mangrove soils contained lower levels of gibbsite, but they are farther away from the source and located in large estuarine systems, where the material has been subject to different processes and has probably been present for a longer period. The presence of significant quantities of gibbsite in mangrove soils has been reported by Marius et al. (1987), who studied mangrove soils in the Brazilian State of Espírito Santo, relating the presence of gibbsite with soils of adjacent areas, originating from Tertiary sediments of the Barreiras Formation.

Gibbsite is not stable in mangrove soils because, according to Michalopoulos and Aller (2004), the existence of high concentrations of biogenic silica and basic cations ( $\mathrm{Ca}$ and $\mathrm{Mg}$ ), mainly in estuarine environments, favors reverse weathering processes, i.e., the neoformation of 1:1 phyllosilicates from $\mathrm{Al}$ oxyhydroxides. This process would involve readsorption of $\mathrm{Si}$ in the gibbsite structure to form kaolinitic minerals, as suggested by Macías and Ojea (1980) for salt marsh environments. According to the consideration above, gibbsite would not be expected to be found in large amounts in mangrove soils.

It can therefore be inferred that the diminishing levels of gibbsite moving southward along the shoreline are related to the sedimentation dynamics. Since Baixada Santista and the south shoreline are more closed environments and the sediments are remobilized within these systems, the particles therefore reside longer in the system, favoring the process of transformation from gibbsite to kaolinite as described above.

Kaolinite is commonly found in estuarine environments, in both tropical and temperate climates (Behling and Costa, 2001, 2004; Belzunce-Segarra et al., 2002; Prada-Gamero et al., 2004). In the present study, kaolinite occurred in the silt and clay fractions in all studied mangrove soils. Like gibbsite, kaolinite is an allochthonous mineral that originates from kao- 
linitic soils adjacent to the coastal plain. Although generally widespread, kaolinite was most abundant in the IGUA mangrove soil, which can be explained by the constant discharge of kaolinitic sediment via the Ribeira do Iguape River (Fig. 9).

Neogenesis of kaolinite via the reverse weathering process, as described above for gibbsite, must also be considered in mangrove soils. The kaolinite present in the silt fraction is possibly a pseudomorphous kaolinite resulting from the weathering of biotite (Kretzschmar et al., 1997; Jolicoeur et al., 2000).

Furthermore, at least part of the smectite in these soils is of detrital origin, and related to the last transgressive and regressive events, i.e., the Cananéia Transgression occurred approximately $120,000 \mathrm{yr}$ before present (BP), correlated to the Sangamonian in North America (Chappell, 1983), and the Santos Transgression, which occurred $5100 \mathrm{yr}$ BP. In the former transgressive event, at least part of the smectites may have been formed in the continental platform, since marine smectites are primarily formed in this environment (Hillier, 1995). Moreover, the platform sediments would have been exposed during the marine regression of the last glacial maximum (about 17,000 yr $\mathrm{BP}$ ) and, finally, they could have been remobilized to the current coastline during the Santos Transgression (5100 yr BP).

Authigenesis of smectite in mangrove soils should also be considered. Chamley (1989) suggested that the precipitation of $\mathrm{Fe}$ and $\mathrm{Si}$ ions dissolved in pore water may occur, which forms neogenic nontronite. Velde and Church (1999) reported that cyclic changes in the redox potential at the soil surface of a salt marsh led to the formation of smectitic minerals from the transformation of illite and chlorite. Smectite may also be formed in this way in mangrove soils as these environments are the tropical equivalent of salt marshes. Smectites are unlikely to be of terrestrial origin in mangrove soils in humid tropical regions. Terrestrial soils around the studied coastal plain rarely contain smectites (Sakai and Lepsch, 1984; Rossi, 1999; Furian et al., 2002; Ishida, 2005).

The mica present in mangroves of the southern coast and the Baixada Santista is possibly muscovite in the silt fraction and illite in the clay fraction. Because of the absence or low intensity of a 0.5 -nm peak, however, the mica in the silt and clay fractions in the mangrove soils from the northern coast must be biotite or even a glauconitic mineral (Fanning et al., 1989; Moore and Reynolds, 1989). In the present study, biotite probably occurred in the clay fraction in northern mangrove soils (RE and RF) because of the close proximity between

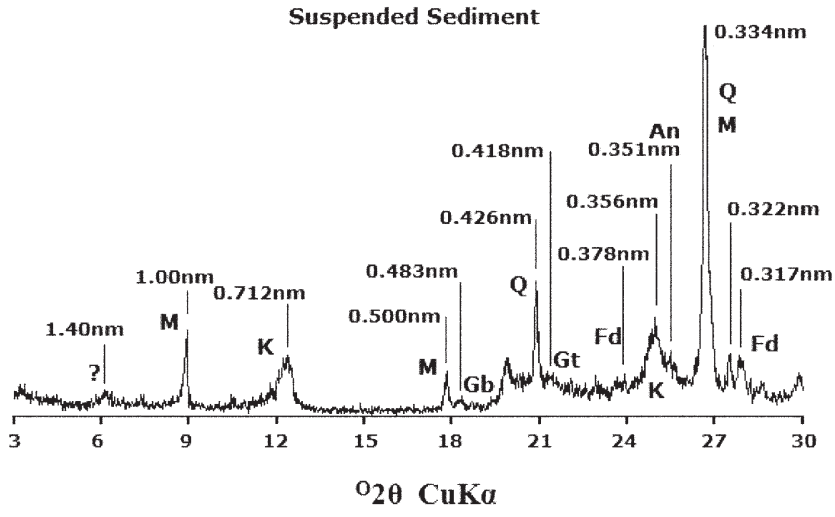

Fig. 9. X-ray diffraction pattern of suspended sediment from the Ribeira de Iguape River; $M=$ mica, $K=$ kaolinite, $F d=$ feldspars, $\mathbf{G b}=$ gibbsite, $\mathbf{G t}=$ goethite, $\mathrm{Q}=$ quartz, $\mathrm{An}=$ anatase.

the complex of crystalline rocks of the Serra do Mar and the mangrove areas. Moreover, the rocks in the crystalline complex around the mangrove forests of the northern shore contain higher levels of maphic minerals (Instituto de Pesquisas Tecnológicas, 1981).

The vermiculite identified in the silt fraction as well as in the clay fraction in RF probably originated from the Serra do Mar soils, since this mineral can occur secondarily in these soils (Furian et al., 2002; Ishida, 2005). It is probably trioctahedral vermiculite originating from the direct transformation of biotite (Douglas, 1989), as suggested by the presence of this mica in the silt and clay fractions in RF.

The transmission electron micrographs demonstrated the presence of tubular halloysite in the RE soil. Halloysite may be formed by the weathering of biotite present in granite and gneiss (Kretzschmar et al., 1997) and also of feldspars (Dixon, 1989). In wet, warm climates under well-drained conditions, generally biotite or feldspars transform to kaolinite (Kretzschmar et al., 1997; Dixon, 1989), so the presence of halloysite in mangrove soils probably would be conserved only if it was kept constantly under poorly drained conditions, as these soils are.

\section{CONCLUSIONS}

The mangrove soils on the coast of São Paulo State present an assemblage consisting of smectite and kaolinite as autochthonous or allochthonous minerals. Essentially allochthonous minerals occurring there are illite, gibbsite, quartz, feldspars,
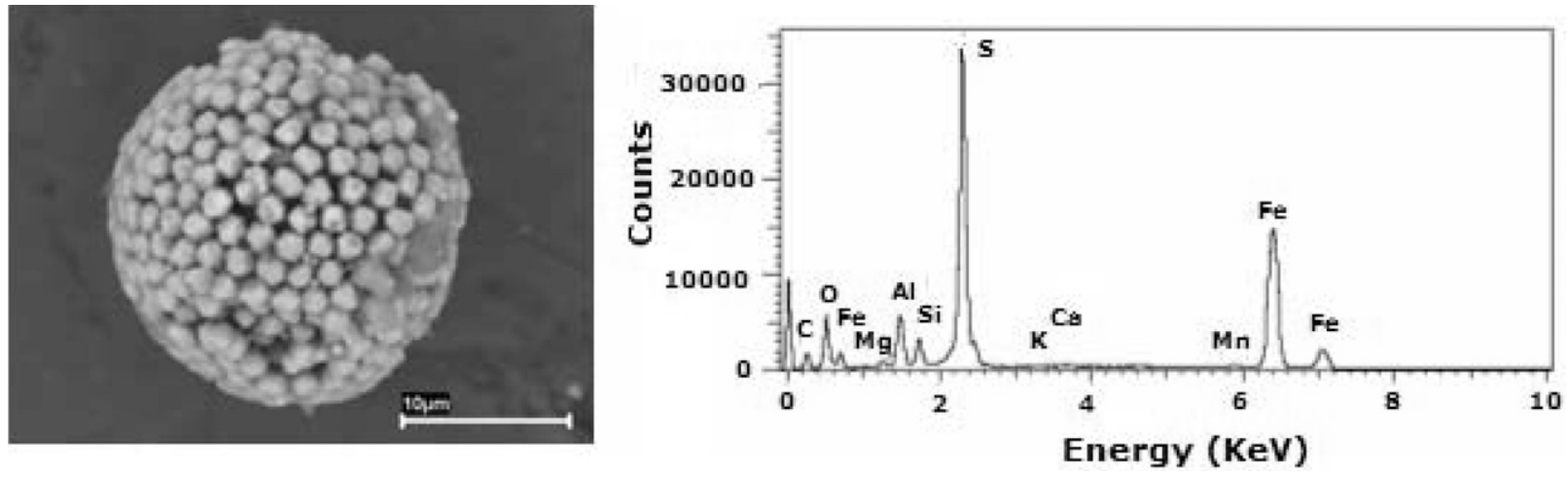

Fig. 10. Scanning electron micrograph and energy dispersive spectrogram of samples from the Itapanhaú River mangrove soil, showing the presence of pyrite framboid in mangrove soils. 
Table 2. Some physical and chemical properties and classification of the representative mangrove soils along the coast of the State of São Paulo.

\begin{tabular}{|c|c|c|c|c|c|c|c|c|}
\hline Depth & Color & $\underset{\text { C }}{\text { Organic }}$ & $\mathrm{pH}$ & $\begin{array}{c}\text { Redox } \\
\text { potential }\end{array}$ & Sand & Silt & Clay & Texture \\
\hline $\mathrm{cm}$ & & $\%$ & & $\mathrm{mV}$ & $\longrightarrow$ & $-\%-$ & & \\
\hline \multicolumn{9}{|c|}{ Pai Matos Island mangrove soil, Typic Sulfaquent } \\
\hline $0-20$ & $2.5 Y 3 / 1$ & 4.9 & 5.0 & 169 & 32 & 30 & 38 & Clay loam \\
\hline $60-80$ & G1 4/N & 4.3 & 6.7 & -96 & 84 & 6 & 10 & Loamy sand \\
\hline \multicolumn{9}{|c|}{ Caranguejo Island mangrove soil, Typic Sulfaquent } \\
\hline $0-20$ & $2.5 Y 3 / 2$ & 5.1 & 6.8 & -46 & 18 & 51 & 31 & Silty clay loam \\
\hline $60-80$ & $5 Y 4 / 1$ & 3.9 & 7.0 & -96 & 13 & 54 & 33 & Silty clay loam \\
\hline \multicolumn{9}{|c|}{$\underline{\text { Itapanhaú River mangrove soil, Typic Sulfihemist }}$} \\
\hline $0-20$ & $2.5 Y 2.5 / 1$ & 12.1 & 6.9 & -182 & 12 & 56 & 32 & Silty clay loam \\
\hline $60-80$ & $\mathrm{G} 13 / \mathrm{N}$ & 9.7 & 7.0 & -267 & 24 & 45 & 31 & Clay loam \\
\hline \multicolumn{9}{|c|}{ Escuro River mangrove soil, Haplic Sulfaquent } \\
\hline $0-20$ & $2.5 Y 2.5 / 1$ & 1.7 & 6.9 & -116 & 93 & 4 & 3 & Sand \\
\hline $60-80$ & $2.5 Y 4 / 1$ & 1.4 & 6.9 & -162 & 85 & 8 & 7 & Sand \\
\hline \multicolumn{9}{|c|}{ Fazenda River mangrove soil, Haplic Sulfaquent } \\
\hline $0-20$ & $2.5 Y 2.5 / 1$ & 3.1 & 6.8 & -30 & 94 & 3 & 3 & Sand \\
\hline 60-80 & $2.5 Y 4 / 1$ & 0.1 & NDt & ND & 97 & 2 & 1 & Sand \\
\hline
\end{tabular}

$\mathrm{TND}=$ Not determined.

goethite, biotite, vermiculite, anatase, and halloysite. The allochthonous minerals found in the mangrove soils of São Paulo are terrestrial in origin and are transported by rivers that drain the coastal plain, and may also originate from the continental platform through tidal currents or as a result of past transgressive events (the Cananéia and Santos Transgressions). The essentially autochthonous mineral occurring there is pyrite, which is formed through of the $\mathrm{SO}_{4}$-reducing process. Neoformation of smectite probably occurs, and also of kaolinite, as a result of the resilication of gibbsite in mangrove soils, a process that would explain the decrease in gibbsite moving southward along the coast, as these sediments have been present for longer in the estuary. The presence of goethite in mangrove soils is related to recent sediment transport to the system and occurs locally. Also locally observed were biotite and vermiculite. The geomorphological settings along the São Paulo State coast affect the distribution of minerals in the mangrove soils.

\section{ACKNOWLEDGMENTS}

This study was partly financed by the Coordenação de Aperfeiçoamento de Pessoal de Nível Superior (CAPES), Dirección General de Universidades del Ministerio de Educación y Ciencia, Spain, and Fundação de Amparo à Pesquisa do Estado de São Paulo, Brazil. We thank the Instituto de Ciencias Agrarias/CSIC, Spain, and the Instituto Oceanográfico, Univ. de São Paulo, Brazil. Many thanks are due to Dorival Grisotto, Humberto, and the others fellows from IO-USP for their help in the field work, and also to María Santiso and Beatriz González for laboratory assistance.

\section{REFERENCES}

Alongi, D.M., B.F. Clough, and A.I. Robertson. 2005. Nutrient-use efficiency in arid-zone forests of the mangroves Rhizophora stylosa and Avicennia marina. Aquat. Bot. 82:121-131.

Alongi, D.M., A. Sasekumar, F. Tirendi, and P. Dixon. 1998. The influence of stand age on benthic decomposition and recycling of organic matter in managed mangrove forests of Malaysia. J. Exp. Mar. Biol. Ecol. 225:197-218.

Andrade, R.C.B., and S.B. Patchineelam. 2000. Especiação de metais-traços em sedimentos de florestas de manguezais com Avicennia e Rhizophora.
Quim. Nova 23:733-736.

Anthony, E.J. 2004. Sediment dynamics and morphological stability of estuarine mangrove swamps in Sherbro Bay, West Africa. Mar. Geol. 208:207-224.

Behling, H., and M.L. Costa. 2001. Holocene vegetational and coastal environmental changes from the Lago Crispim record in northeastern Pará State, eastern Amazonia. Rev. Palaeobot. Palynol. 114:145-155. Behling, H., and M.L. Costa. 2004. Mineralogy, geochemistry, and palynology of modern and late Tertiary mangrove deposits in the Barreiras Formation of Mosqueiro Island, northeastern Pará state, eastern Amazonia. J. S. Am. Earth Sci. 17:285-295.

Belzunce-Segarra, M.J., M.J. Wilson, A.R. Fraser, E. Lachowski, and D.M.L. Duthie. 2002. Clay mineralogy of Galician coastal and oceanic surface sediments: Contributions from terrigenous and authigenic sources. Clay Miner. 37:23-37.

Biscaye, P.E. 1965. Mineralogy and sedimentation of Recent deep sea clay in the Atlantic Ocean and adjacent seas and oceans. Geol. Soc. Am. Bull. 76:803-832.

Bosire, J.O., F. Dahdough-Guebas, J.G. Kairo, J. Kazungu, F. Dehairs, and N. Koedam. 2005. Litter degradation and $\mathrm{CN}$ dynamics in reforested mangrove plantations at Gazi Bay, Kenya. Biol. Conserv. $126: 287-295$

Brown, G. 1980. Associated minerals. p. 361-410. In G.W. Brindly and G. Brown (ed.) Crystal structures of clay minerals and their x-ray identification. Mineral. Soc., London.

Caliani, J.C.F., F.R. Muñoz, and E. Galán. 1997. Clay mineral and heavy metal distributions in the lower estuary of Huelva and adjacent Atlantic shelf, SW Spain. Sci. Total Environ. 198:181-200.

Canfield, D.E., B. Thamdrup, and J.W. Hansen. 1993. The anaerobic degradation of organic matter in Danish coastal sediments: Iron reduction, manganese reduction, and sulfate reduction. Geochim. Cosmochim. Acta 57:3867-3883.

Chamley, H. 1989. Clay sedimentology. Springer-Verlag, Berlin.

Chappell, J.M.A. 1983. A revised sea-level record of the last 300000 years from Papua New Guinea. Search 14:99-104.

Clark, M.W., D. McConchie, D.W. Lewis, and P. Saenger. 1998. Redox stratification and heavy metal partitioning in Avicennia-dominated mangrove sediments: A geochemical model. Chem. Geol. 149:147-171.

Cohen, M.C.L., P.W.M. Souza-Filho, R.J. Lara, H. Behling, and R.J. Ângulo. 2005. A model of Holocene mangrove development and relative sea-level changes on the Braganc, a peninsula (northern Brazil). Wetlands Ecol. Manage. 13:433-443.

Comissao de Solos. 1960. Levantamento de reconhecimento dos solos do Estado de São Paulo (contribuição à carta de solos do Brasil. Boletim do Servico Nacional de Pesquisas Agron. 12. Centro Nacional de Ensino e Pesquisas Agronomicas, Rio de Janeiro.

Cooper, J.A.G. 2001. Geomorphological variability among microtidal estuaries from the wave-dominated South African coast. Geomorphology 40:99-122.

Costa, M.L., H. Behling, J.F. Berrêdo, M.S. Carmo, and N.V.M. Siqueira. 2004. Mineralogical, geochemical and palynological studies of late holocene mangrove sediments from northeastern Pará State, Brazil. Rev. Bras. Geocienc. 34:479-488.

Dillenburg, S.R., L. Laybauer, A.S. Mexias, N. Dani, E.G. Barboza, and C. Lummertz Netto. 2000. Significado estratigráfico de minerais glauconíticos da planície costeira do Rio Grande do Sul, região da Laguna de Tramandaí. Rev. Bras. Geocienc. 30:649-654.

Dixon, J.B. 1989. Kaolin and serpentine group minerals. p. 467-525. In J.B. Dixon and S.B. Weed (ed.) Minerals in soil environments. 2nd ed. SSSA Book Ser. 1. SSSA, Madison, WI.

Doner, H.E., and W.C. Lynn. 1989. Carbonate, halide, sulfate, and sulfide minerals. p. 279-330. In J.B. Dixon and S.B. Weed (ed.) Minerals in soil environments. 2nd ed. SSSA Book Ser. 1. SSSA, Madison, WI.

Dong, G., Y.M. Nelson, L.W. Lion, M.L. Shuler, and C. Ghiorse. 2000. Adsorption of $\mathrm{Pb}$ and $\mathrm{Cd}$ onto metal oxides and organic material in natural surface coatings as determined by selective extractions: New evidence for the importance of $\mathrm{Mn}$ and Fe oxides. Water Res. 34:427-436.

Douglas, L.A. 1989. Vermiculite. p. 635-674. In J.B. Dixon and S.B. Weed (ed.) Minerals in soil environments. 2nd ed. SSSA Book Ser. 1. SSSA, Madison, WI. 
Drees, L.R., L.P. Wilding, N.E. Smeck, and A.L. Senkay. 1989. Silica in soils: Quartz and disordered silica polymorphs. p. 913-974. In J.B. Dixon and S.B. Weed (ed.) Minerals in soil environments. 2nd ed. SSSA Book Ser. 1. SSSA, Madison, WI.

Fanning, D.S., V.Z. Keramidas, and M.A. El-Desoky. 1989. Micas. p. 551-634. In J.B. Dixon and S.B. Weed (ed.) Minerals in soil environments. 2nd ed. SSSA Book Ser. 1. SSSA, Madison, WI.

Fanning, D.S., M.C. Rabenhorst, S.N. Burch, K.R. Islam, and A. Tangren. 2002. Sulfides and sulfates. p. 229-260. In J.B. Dixon and D.G. Schulze (ed.) Soil mineralogy with environmental applications. SSSA Book Ser. 7. SSSA, Madison, WI.

Faria, M.M., and B.A. Sanchez. 2001. Geochemistry and mineralogy of recent sediments of Guanabara Bay (NE sector) and its major rivers-Rio de Janeiro State-Brazil. An. Acad. Bras. Cienc. 73:121-133.

Ferreira, T.O. 2006. Processos pedogenéticos e biogeoquímica de 'Fe' e 'S' em solos de manguezais-SP. Ph.D. diss. Escola Superior de Agricultura "Luiz de Queiroz", Univ. de São Paulo, São Paulo, Brazil.

Ferreira, T.O., X.L. Otero, P. Vidal-Torrado, and F. Macías. 2007a. Redox processes in mangrove soils under Rhizophora mangle in relation to different environmental conditions. Soil Sci. Soc. Am. J. 71:484-491.

Ferreira, T.O., X.L. Otero, P. Vidal-Torrado, and F. Macías. 2007b. Effects of bioturbation by root and crab activity on iron and sulfur biogeochemistry in mangrove substrate. Geoderma 142:36-46.

Ferreira, T.O., P. Vidal-Torrado, X.L. Otero, and F. Macías. 2007c. Are mangrove forest substrates sediments or soils? A case study in southeastern Brazil. Catena 70:79-91.

Fortin, D., G. Leppard, and A. Tessier. 1993. Characteristics of lacustrine diagenetic iron oxyhydroxides. Geochim. Cosmochim. Acta 27:4391-4404.

Furian, S., L. Barbiero, R. Boulet, P. Curmi, M. Grimaldi, and C. Grimaldi. 2002. Distribution and dynamics of gibbsite and kaolinite in an Oxisol of Serra do Mar, southeastern Brazil. Geoderma 106:83-100.

Furukawa, K., E. Wolanski, and H. Mueller. 1997. Currents and sediment transport in mangrove forests. Estuarine Coastal Shelf Sci. 44:301-310.

Heroy, D.C., S.A. Kuehl, and S.L. Goodbred, Jr. 2003. Mineralogy of the Ganges and Brahmaputra rivers: Implications for river switching and Late Quaternary climate change. Sediment. Geol. 155:343-359.

Hillier, S. 1995. Erosion, sedimentation and sedimentary origin of clays. p. 162-219. In B. Velde (ed.) Origin and mineralogy of clays. Springer-Verlag, Berlin.

Howarth, R.W., and S. Merkel. 1984. Pyrite formation and the measurement of sulfate reduction in salt marsh sediments. Limnol. Oceanogr. 29:598-608.

Instituto de Pesquisas Tecnológicas. 1981. Mapa geológico do Estado de São Paulo. Secretaria de Ciência Tecnologia e Desenvolvimento Econômico, São Paulo, Brazil.

Ishida, D.A. 2005. Estudo macro e micromorfológico de seqüência de solos em microbacia hidrográfica no núcleo Cunha-Indaiá no Parque Estadual da Serra do Mar-SP. M.S. thesis. Inst. de Geociência, Univ. de São Paulo, São Paulo, Brazil.

Jackson, M.L. 1969. Soil chemical analysis-Advanced course. Published by M.L. Jackson, Madison, WI.

Jolicoeur, S., P. Ildefonse, and M. Bouchard. 2000. Kaolinite and gibbsite weathering of biotite within saprolites and soils of central Virginia. Soil Sci. Soc. Am. J. 64:1118-1129.

Kämpf, N., and U. Schwertmann. 1982. The 5-M-NaOH concentration treatment for iron oxides in soils. Clays Clay Miner. 30:401-408.

Kretzschmar, R., W.P. Robarge, A. Moozegar, and M.J. Vepraskas. 1997. Biotite alteration to halloysite and kaolinite in soil-saprolite profiles developed from mica schist and granite gneiss. Geoderma 75:155-170.

Ku, T.C.W., and L.M. Walter. 2003. Syndepositional formation of Fe-rich clays in tropical shelf sediments, San Blas Archipelago, Panama. Chem. Geol. 197:197-213.

Lamparelli, C.C. 1998. Mapeamento dos ecossistemas costeiros do Estado de São Paulo. Companhia de Tecnologia de Saneamento Ambiental, São Paulo, Brazil.

Liaghati, T., M. Preda, and M. Cox. 2003. Heavy metal distribution and controlling factors within coastal plain sediments, Bells Creek catchment, southeast Queensland, Australia. Environ. Int. 29:935-948.

Lovley, D.R. 1991. Dissimilatory Fe (III) and Mn (IV) reduction. Microbiol. Rev. 55:259-287.

Macías, F.V., and G. Ojea. 1980. La presencia de gibsita en suelos de climas templados: Una revisión de los conocimientos actuales. An. Edafol. Agrobiol. 39:301-341.

Marchand, C., E. Lallier-Vergès, F. Baltzer, P. Albéric, D. Cossa, and P. Baillif. 2006. Heavy metal distribution in mangrove sediments along the mobile coastline of French Guiana. Mar. Chem. 98:1-17.

Marius, C., D. Archanjo, and P. Larque. 1987. Les sols de mangroves de la baie de Vitoria (Brésil). Cah. ORSTOM Ser. Pedol. 23:211-216.

Marius, C., and J. Lucas. 1991. Holocene mangrove swamps of West Africa: Sedimentology and soils. J. Afr. Earth Sci. 12:41-54.

Michalopoulos, P., and R.C. Aller. 2004. Early diagenesis of biogenic silica in the Amazon delta: Alteration, authigenic clay formation, and storage. Geochim. Cosmochim. Acta 68:1061-1085.

Milnes, A.R., and R.W. Fitzpatrick. 1989. Titanium and zirconium minerals. p. 1131-1205. In J.B. Dixon and S.B. Weed (ed.) Minerals in soil environments. 2nd ed. SSSA Book Ser. 1. SSSA, Madison, WI.

Moore, D.M., and R.C. Reynolds, Jr. 1989. X-ray diffraction and the identification and analysis of clay minerals. Oxford Univ. Press, New York.

Petschick, R., G. Kuhn, and F. Gingele. 1996. Clay mineral distribution in surface sediments of the South Atlantic: Sources, transport, and relation to oceanography. Mar. Geol. 130:203-229.

Prada-Gamero, R.M., P. Vidal-Torrado, and T.O. Ferreira. 2004. Mineralogia e Físico-Química dos Solos de Mangue do Rio Iriri no Canal de Bertioga (Santos, SP). Rev. Bras. Cienc. Solo 28:233-244.

Rossi, M. 1999. Fatores formadores da paisagem litorânea: A bacia do Guaratuba, São Paulo-Comissao de Solos. Ph.D. diss. Faculdade de Filosofia, Letras e Ciências Humanas, Univ. de São Paulo, São Paulo, Brazil.

Sakai, E., and I.F. Lepsch. 1984. Levantamento pedológico detalhado da estação experimental de Pariqüera Açu. Boletim Técnico 83. Inst. Agronômico, Campinas, São Paulo, Brazil.

Schultz, L.G. 1964. Quantitative interpretation of mineralogical composition from x-ray and chemical data for the Pierre shale. U.S. Geol. Surv. Prof. Pap. 391-C.

Smith, P.T. 1996. Physical and chemical characteristics of sediments from prawn farms and mangrove habitats on the Clarence River. Aquaculture 146:47-83.

Smoak, J.M., and S.R. Patchineelam. 1999. Sediment mixing and accumulation in a mangrove ecosystem: Evidence from ${ }^{210} \mathrm{~Pb},{ }^{234} \mathrm{Th}$ and ${ }^{7}$ Be. Mangroves Salt Marshes 3:17-27.

Suguio, K., and L. Martin. 1978. Formações quaternárias marinhas do litoral paulista e sul fluminense. Inst. Oceanográfico, São Paulo, Brazil.

Suguio, K., and M.G. Tessler. 1992. Depósitos quaternários da planície costeira de Cananéia-Iguape (SP). Publ. Esp. Inst. Oceanogr. 9:1-33.

Van Cappellen, P., and Y. Wang. 1996. Cycling of iron and manganese in surface sediments. A general theory for carbon, oxygen, nitrogen, sulfur, iron, and manganese. Am. J. Sci. 296:197-243.

Velde, B., and T. Church. 1999. Rapid clay transformations in Delaware salt marshes. Appl. Geochem. 14:559-568. 